Article

\title{
Phytotoxic Effect of Herbicides on Various Camelina [Camelina sativa (L.) Crantz] Genotypes and Plant Chlorophyll Fluorescence
}

\author{
Łukasz Sobiech ${ }^{1, *(D)}$, Monika Grzanka ${ }^{1}\left(\mathbb{D}\right.$, Danuta Kurasiak-Popowska ${ }^{2}(\mathbb{D}$ and \\ Dominika Radzikowska ${ }^{1}$ (D) \\ 1 Agronomy Department, Faculty of Agronomy and Bioengineering, Poznan University of Life Sciences, \\ 60-632 Poznan, Poland; monika.grzanka@up.poznan.pl (M.G.); dominika.radzikowska@up.poznan.pl (D.R.) \\ 2 Genetics and Plant Breeding Department, Faculty of Agronomy and Bioengineering, Poznan University of \\ Life Sciences, 60-632 Poznan, Poland; danuta.kurasiak-popowska@up.poznan.pl \\ * Correspondence: lukasz.sobiech@up.poznan.pl; Tel.: +48-61-848-7599
}

Received: 20 April 2020; Accepted: 21 May 2020; Published: 23 May 2020

\begin{abstract}
Camelina is an oil plant classified as a minor crop. The small acreage is the main cause of the small amount of plant protection products that are registered for use on camelina plantations. This contributes to difficulties in the protection of this plant. In the conducted experiment, the genetic similarity of genotypes of camelina was compared. The effect of selected herbicides (propaquizafop at rate $70 \mathrm{~g}$ a.i. $\mathrm{ha}^{-1}$, quizalofop-p-ethyl at rate $50 \mathrm{~g}$ a.i. ha ${ }^{-1}$, clopyralid at rate $90 \mathrm{~g}$ a.i. $\mathrm{ha}^{-1}$, and picloram at rate $24 \mathrm{~g}$ a.i. $\mathrm{ha}^{-1}$ applied in the three-four-leaves growth stage of camelina) on six individual genotypes of the plant and plant chlorophyll fluorescence after the use of these substances was also determined. The Przybrodzka variety showed the lowest level of damage in the assessment carried out 42 days after herbicide application and the damages of plants after quizalofop-p-ethyl and propaquizafop was completely gone. The variety Przybrodzka had the lowest genetic similarity to all analyzed genotypes. In other cases, genetic similarity of analyzed genotypes could not be linked to herbicide-related damage. Picloram contributed to the greatest damage to test plants and had the greatest impact on the operation of photosystem II (PSII). However, the level of plant chlorophyll fluorescence parameter values indicates small PSII damage for all substances and the possibility of subsequent plant regeneration. The results of the presented research indicate that it is worth referring to several plant varieties in phytotoxicity studies of herbicides towards arable crops.
\end{abstract}

Keywords: camelina; herbicides; genetic similarity; phytotoxicity; formulation; plant chlorophyll fluorescence

\section{Introduction}

One of the features of modern agriculture is the simplification of crop rotation [1]. Diversity in agriculture plays an important role, both in terms of preserving biodiversity and the agricultural environment and protecting crops against pests, diseases, and weeds [2,3]. Therefore, it is worth looking for plants that can diversify the species composition of contemporary farming plants. Camelina is a self-pollinating annual plant belonging to the Brassicaceae family. The vegetation period of spring forms in the climatic conditions of Poland is about 100-130 days, while winter forms are 280-300 days. The first of these forms is mainly grown in the world. Plant height in the case of spring camelina varies in the range of $50-90 \mathrm{~cm}$; for winter forms it is $80-120 \mathrm{~cm}$. The diameter of the flowers is $5-7 \mathrm{~mm}$. The fruit of the plant in question is the silicule, in which there are 8-15 seeds reaching a length of about $2 \mathrm{~mm}$. The mass of one thousand seeds is about $0.8-1.8 \mathrm{~g}$ [4]. 
Drought is becoming a growing problem in agricultural production in the world $[5,6]$. Camelina is considered a plant with low water requirements [7]. The production of phytalexins exhibiting antimicrobial activity and the limited area of cultivation of camelina contribute to the fact that this plant is characterized by high resistance to diseases and pests [8]. In the cultivation of camelina, the main problem is the presence of weeds, whose quantity and fresh mass are sometimes greater than on plantations of other plants belonging to the Brassicaceae family [9].

Camelina was an important oilseed plant in Europe until the mid-20th century, especially in the northern and central parts of the continent. Later, its production level decreased [10]. In recent years, interest in camelina has been noted due to the unique composition of oil obtained from camelina. High oil content (28-40\%) [11] makes it a suitable oil source for biodiesel production [12]. Camelina oil is rich in oleic $(18: 1,14-16 \%)$, linoleic $(18: 2,15-23 \%)$, linolenic $(18: 3,31-40 \%)$, and eicosenoic $(20: 1$, $12-15 \%)$ acid [13].

The most attention is paid to the use of camelina oil for the production of biodiesel, renewable diesel, and renewable jet fuel $[13,14]$. The first tests of hydroprocessed renewable jet fuel (a mixture of the branched aromatics and the C7-C18 branched alkanes) were carried out by the US Air Force in 2009 [15]. Since then, numerous fighter jets (Thunderbirds) and jets (KLM Royal Dutch and Japan Airlines) have been successfully tested on a blend of JP-8 (typical jet fuel) and camelina-derived jet fuel [13].

Camelina oil is also used in the food industry as functional food and in the cosmetics industry [16]. Camelina oil can be used in the petrochemical-based polymer industry, because epoxidized camelina oil has the properties of peel adhesion and, after further formulation, the potential to be used for preparation of pressure-sensitive adhesives, coating, or resin [17].

Camelina meal, or ground camelina oil cake or press cake, which is a by-product of the oil extraction process can be used as animal feed $[18,19]$. The US Food and Drug Administration (USDA) approved the use of camelina meal in feed rations given to beef cattle and broiler chickens, provided that the percentage is not higher than $10 \%$ [20].

The possibility of full use of Camelina sativa is highly economically advantageous. The cost of producing fuel for Camelina sativa grown in Canada was USD 0.83/L, with approximately $88 \%$ of the total production cost resulting from the cost of feedstock [21].

Due to the fact that this plant is grown in a small area, the availability of plant protection products registered for use in this crop is an important problem. In the European Union, the availability of plant protection products registered for use in this crop is a limitation. However, it closes within the limits of several active substances that can be used [22].

Winter oilseed rape is the most important oilseed plant in Europe [23]. Herbicides registered for use in this include propaquizafop, quizalofop-p-ethyl, clopyralid, and picloram [24]. Camelina and winter oilseed rape belong to the same family; hence, it is likely that these herbicides could also be used in minor crops such as camelina. However, it is important to determine the phytotoxicity of these herbicides to camelina. Determining the impact of herbicides on crop development is also important in the context of different varieties, which is associated with their intraspecific variability [25].

Propaquizafop and quizalofop-p-ethyl are herbicides that belong to the group of aryloxyphenoxypropionates [26,27]. Aryloxyphenoxypropionates are classified as inhibitors of acetyl coenzyme A carboxylase (ACCase inhibitors) [28]. This enzyme is involved in the synthesis of fatty acids [29]. It catalyzes the reaction of attaching carbon dioxide to acetyl-CoA, resulting in the formation of malonyl-CoA. There are two forms of this enzyme in plant cells-prokaryotic and eukaryotic. The latter of these forms is sensitive to the effects of these herbicides [30]. Most higher plants have both forms of CoA acetyl carboxylase. The exception are plants from the family Gramineae, in which only the eukaryotic form is found [31]. Weeds belonging to this family are therefore sensitive to the action of herbicides belonging to the inhibitors of acetyl coenzyme A carboxylase [32].

Clopyralid and picloram are substances classified as pyridine carboxylates. They belong to the group of synthetic auxins [33]. These herbicides mimic the action of excessive amounts of indole-3-acetic 
acid (IAA), which is the main natural phytohormone found in higher plants [34]. The reason for the selectivity of these preparations for monocots is not yet known [35].

Chlorophyll fluorescence is becoming a very powerful tool in agricultural, environmental, and ecological research [36]; along with increasing the sensitivity of fluorimeters measurement, these methods become also useful in ecotoxicological studies [37]. The chlorophyll fluorescence signal can be used as a probe for photosynthetic activity [38]. As is known, plant stress, both biotic and abiotic, negatively affects the physiological state of plants and their photosynthetic activity. Plant protection treatments, including herbicidal ones, cause short-term stress in crops, whereas they are toxic to the undesirable plants (weed). In many cases, herbicidal preparations directly reduce photosynthetic activity or indirectly cause damage to plants, which in turn reduces the efficiency of photosynthesis. Herbicides that directly affect PS-II usually work by inhibiting the transport of electrons in PS-II [39]. Analysis of chlorophyll fluorescence can yield important information on how herbicides interfere with photosystem I and II mechanisms [40]. The assessment of the physiological state of the photosynthetic apparatus is performed on the basis of analyses of several groups of measured and calculated parameters based on induction and general identification of two different states of the photosynthetic apparatus: photochemically inactive (after adaptation to the dark) - electron transport is completely stopped, the $\mathrm{H}^{+}$gradient across thylakoid membranes is minimal, the concentration of NADPH and ATP is minimal—and photochemically active (after adaptation of the sample to light)—NADPH and ATP synthesis and $\mathrm{CO}_{2}$ binding occur. In addition, the technique for measuring chlorophyll fluorescence allows the recording of changes occurring in PSII under the influence of stress factors before visual symptoms are seen, which makes this technique the perfect complement to the visual assessment of phytotoxicity. Chlorophyll fluorescence measurement is a non-destructive tool that allows scientists to obtain information on the photosynthesis process without destroying the test sample [41].

The aim of the study is to assess the effect of selected herbicides on different camelina genotypes, compare the sensitivity of different genotypes with the genetic distance between them, and determine the effect of herbicides on plant chlorophyll fluorescence.

\section{Materials and Methods}

\subsection{Genetic Distance Testing}

\subsubsection{Plant material}

The spring variety Omega and winter varieties Luna and Przybrodzka of camelina were obtained from the Polish National Plant Breeders' Rights (PBR). The winter genotype Lenka has been protected by temporary rights in Poland since 2017. The spring 57L3 genotype is stable breeding material. All of the above genotypes were bred at the Poznań University of Life Sciences (Poznań, Poland) [42]. The spring genotype Hoga (PI 650150) collected in Denmark came from the US National Plant Germplasm System (NPGS, Copenhagen, Denmark).

\subsubsection{DNA Extraction}

DNA was isolated from the leaves of 10-day-old seedlings with the use of an extraction kit (Genomic Mini AX Plant, A\&A Biotechnology, Gdynia, Poland) by means of the column-based method.

\subsubsection{Random Amplified Polymorphic DNA Assays}

The RAPD-PCR reaction was carried out in a $12.5 \mu \mathrm{L}$ mixture consisting of: water, $1 \mathrm{M}$ Tris $\mathrm{HCl}$ ( $\mathrm{pH}$ 8.3), $2 \mathrm{mM} \mathrm{MgCl} 2,2 \mathrm{mM}$ dNTP, $5 \mathrm{pmol} / \mu \mathrm{L}$ primer, $5 \mathrm{U} / \mu \mathrm{L}$ Taq polymerase, $25 \mathrm{ng} / \mu \mathrm{L}$ DNA extract. The temperature regime was set to an initial denaturation of $60 \mathrm{~s}$ at $94{ }^{\circ} \mathrm{C}$, followed by 34 cycles $\left(60 \mathrm{~s}\right.$ at $94{ }^{\circ} \mathrm{C}, 45 \mathrm{~s}$ at primer annealing at the optimal temperature, $30 \mathrm{~s}$ at $72{ }^{\circ} \mathrm{C}$ ), and finishing with an extension step of $5 \mathrm{~min}$ at $72{ }^{\circ} \mathrm{C}$. The PCR was carried out in a T Professional Basic Gradient 
Thermocycler. A set of 20 10-mer RAPD-PCR primers was used for DNA amplification (Supplementary Table S1).

\subsubsection{Microsatellite Markers of DNA Assays}

A set of 7 primer pairs (P3H4, P4B3, P4C2, P4H3, P6C2, P6E4, P7D4) was used for DNA amplification according to the method developed by Manca et al. [43]. The polymerase chain reaction (PCR) was conducted in a mixture composed of water, $5 \mu \mathrm{L}$; DreamTaqTMGreen PCR Master Mix, $6.25 \mu \mathrm{L}$; primers, $2 \times 0.25 \mu \mathrm{L}$ (final concentration was $20 \mu \mathrm{M}$ ); and DNA matrix, $1 \mu \mathrm{L}$. The amplification took place under the following conditions: initial denaturation for $5 \mathrm{~min}$ at $94^{\circ} \mathrm{C}, 40$ cycles (denaturation at $94{ }^{\circ} \mathrm{C}$ for $30 \mathrm{~s}$, primer annealing at the optimal temperature for $30 \mathrm{~s}$, synthesis $72{ }^{\circ} \mathrm{C}$ for $30 \mathrm{~s}$ ), final synthesis $72{ }^{\circ} \mathrm{C}$ for $30 \mathrm{~min}$. Two slightly different touchdown PCR protocols called TD1 and TD2 were used for selected primers (P4H3, P6C2, and P7D4). The TD1 profile consisted of initial denaturation for $5 \mathrm{~min}$ at $94^{\circ} \mathrm{C}$, followed by 10 cycles of $30 \mathrm{~s}$ at $94^{\circ} \mathrm{C}$, annealing for $30 \mathrm{~s}$ at a temperature of $65^{\circ} \mathrm{C}$ reduced by $1{ }^{\circ} \mathrm{C}$ every cycle, and for $30 \mathrm{~s}$ at $72{ }^{\circ} \mathrm{C}$. This was followed by 30 cycles of $30 \mathrm{~s}$ at $94{ }^{\circ} \mathrm{C}, 30 \mathrm{~s}$ at $55^{\circ} \mathrm{C}, 30 \mathrm{~s}$ at $72{ }^{\circ} \mathrm{C}$, and one final extension step at $72{ }^{\circ} \mathrm{C}$ for $30 \mathrm{~min}$. The TD2 program differed from the TD1 profile in the annealing temperature and number of cycles. The annealing temperature was reduced in steps of $0.5^{\circ} \mathrm{C}$ in each cycle $\left(8\right.$ cycles) from $54^{\circ} \mathrm{C}$ to $50{ }^{\circ} \mathrm{C}$, followed by 32 cycles at $50^{\circ} \mathrm{C}$.

\subsubsection{Electrophoresis Conditions}

The PCR products were separated by electrophoresis lasting $90 \mathrm{~min}$ at $100 \mathrm{~V}$ in $1.5 \%$ agarose gels containing TBE buffer. Next, they were visualized under UV light after being stained with ethidium bromide. To visualize PCR products, a Molecular Imager Gel Doc ${ }^{\mathrm{TM}}$ XR UV transilluminator was used with the ImageLab ${ }^{\mathrm{TM}}$ Software (Bio-Rad, Hercules, CA, USA).

\subsubsection{Statistical Analysis}

The coefficients of genetic similarity (S) between the cultivars were calculated using the formula developed by Nei and Li [44]:

$$
\mathrm{Sij}=\frac{2 \mathrm{Nij}}{\mathrm{Ni}+\mathrm{Nj}}
$$

where:

$\mathrm{Nij}$ is the number of alleles present in the ith and jth cultivars,

$\mathrm{Ni}$ is the number of alleles present in the ith cultivar,

$\mathrm{Nj}$ is the number of alleles present in the jth cultivar, and

$\mathrm{i}, \mathrm{j}=1,2, \ldots, 20$.

The cultivars were grouped hierarchically according to the coefficients, using the unweighted pair group method of arithmetic means (UPGMA). The relationships between genotypes were presented in a dendrogram.

\subsection{Greenhouse Experiment}

Camelina were grown for 76 days in a greenhouse on photoperiod $16 \mathrm{~h}$ day $/ 8 \mathrm{~h}$ night. Greenhouse temperature was maintained at $25 \pm 2{ }^{\circ} \mathrm{C}$ during the day and at $20 \pm 2{ }^{\circ} \mathrm{C}$ during the night. Camelina were planted in the greenhouse in plastic pots $(1.0 \mathrm{~L}, 15 \mathrm{~cm}$ diameter) containing a mixture of peat and soil at a 1:1 ratio. Soil moisture was systematically measured by ML3 ThetaProbe Soil Moisture Sensor (ThetaProbe, Eijkelkamp, The Netherlands). By regular replenishment, the appropriate weight of pots was maintained at $65-75 \%$ of soil water capacity. Relative air humidity was around $50-80 \%$. Natural sunlight with an intensity of $600 \mu \mathrm{E} \mathrm{m}^{-2} \mathrm{~s}^{-1}$ was supplemented with sodium lamps (HPS) with a capacity of $400 \mathrm{~W}$ (Elektro-Valo Oy. Netafim. Avi: 13473, Uusikaupunki, Finland). Two weeks after emergence, camelina plants were thinned to 6 uniform seedlings per pot. 
Herbicides were applied at doses recommended for use in winter rapeseed cultivation. Tested herbicides were: propaquizafop at rate $70 \mathrm{~g}$ a.i. (active ingredient) ${ }^{*} \mathrm{ha}^{-1}$ (Agil S $100 \mathrm{EC}$, Adama Agan Ltd, Airport city, Israel), quizalofop-p-ethyl at rate $50 \mathrm{~g}_{\text {a.i. }}{ }^{*} \mathrm{ha}^{-1}$ (Targa Super $05 \mathrm{EC}$, Nissan Chemical Europe, Saint-Didier-au-Mont-d'Or, France), clopyralid at rate $90 \mathrm{~g}$ a.i. ha ${ }^{-1}$ (Major 300 SL, Innvigo Sp. z o.o., Warsaw, Poland), and picloram at rate 24 g a.i. ${ }^{*} \mathrm{ha}^{-1}$ (Zorro $300 \mathrm{SL}$, Innvigo Sp. z o.o., Warsaw, Poland). Herbicides have been applied in the three-four-leaves growth stage of camelina.

Treatments were applied using a spray chamber with Tee Jet 1102 (TeeJet Technologies GmbH, Schorndorf, Germany) nozzles delivering $200 \mathrm{~L}^{*} \mathrm{ha}^{-1}$ at $0.2 \mathrm{MPa}$. Water used for herbicide application contained (mg/L): $114 \mathrm{Ca}^{2+}, 7.4 \mathrm{Mg}^{2+}, 0 \mathrm{Na}^{+}, 0 \mathrm{~K}^{+},<1 \mathrm{Fe}^{3+}, 356 \mathrm{CaCO}_{3}$, and $\mathrm{pH}$ 7.3. Camelina plants were assessed 21 and 42 days after treatment (DAT) by estimating the herbicidal phytotoxicity compared to untreated control. The data was calculated using the Henderson-Tilton formula [45]. Visual evaluation of the herbicidal phytotoxicity was based on the comparison of the condition of camelina plants from objects treated with herbicides with plants from the untreated control. Visual phytotoxicity was shown using a scale ranging from $0 \%$ (untreated) to $100 \%$ (completely destroyed plant). The greenhouse trial was designed as a randomized complete block with four replications. Four herbicide variants and untreated controls for six camelina genotypes were tested in each series, resulting in 30 combinations (120 replicates) in both series. Assessments were made for two series of tests. They were made in accordance with EPPO Standards PP 1/49 (3) [46]. At the end of the experiments, the weight of the plants was tested (data not shown). Statistical analysis was conducted using Statistica software (Version 12, StatSoft Inc., Tulsa, OK, USA). Data were subjected to ANOVA followed by Tukey's protected LSD test at the 0.05 probability level.

\subsection{Plant Chlorophyll Fluorescence}

Chlorophyll fluorescence was measured at the first young fully mature healthy leaf with Multi-Mode Chlorophyll Fluorometer (OS5p, Opti-Sciences, Inc., Hudson, USA) with PAR Clip. The Fv/Fm protocol was selected [47]. Fluorescence measurements were done in triplicate for each replication, which gives 12 results for combination for one series of test. Measurements were made 14 and 21 days after herbicide application. Before the measurements, the leaves were dark-adapted for 30 minutes using white clips to silence photosynthesis. Measurements were made at the same time of day, at midday. Settings fluorometer protocols were selected according to the OS5p User's Guide, the standard in Plant Stress Measurement, Opti-Sciences, as follow: Modulation Source: Red, Modulation Intensity: 15, Detector Gain: 05, Saturation Flash Intensity: 29 (non-nominated units). Before measurement, settings parameters were adjusted to an appropriate level. Modulation intensity and detector gain values were adjusted so that the set $\mathrm{Ft}$ (fluorescence signal) was stable and in the range of 150-250 counts, which means that modulated illumination is not driving photosynthesis. Similarly, based on the values of the measured parameters, the saturation flash intensity was determined to get the saturation point. The following parameters were measured: F0-minimum fluorescence, $\mathrm{Fm}$-maximum fluorescence, $\mathrm{Fv}$ - variable fluorescence. The following parameters were calculated: Fv/Fm-Maximum Photochemical Efficiency of Photosystem II; Fv/Fm $=(F m-F 0) / F m$. Statistical analysis of average results for all tested genotypes was conducted using Statistica software (Version 12, StatSoft Inc., Tulsa, OK, USA). Data were subjected to ANOVA followed by Tukey's protected LSD test at the 0.05 probability level.

\section{Results}

\subsection{Genetic Distance Testing}

To assess genetic variation of Camelina sativa genotypes, RAPD (random amplified polymorphic DNA) and SSR (simple-sequence repeats also known as microsatellites) analyses were carried out. Finally, 6 polymorphic PCR products were obtained from SSR analysis (P4C2 and P6C2 were monomorphic) and 69 for RAPD analysis. 
The RAPD and SSR data were used for grouping genotypes by the UPGMA method. The relationship among genotypes is presented in the form of a dendrogram (Figure 1). Genotypes (spring and winter) from Polish breeding of the last 20 years had the greatest genetic similarity: Omega (registered in PBR in 2013), Luna (registered in PBR in 2012), Lenka (in registration process), and the stabilized breeding line 57L3. The old Polish variety Przybrodzka was characterized by the lowest genetic similarity to all analyzed genotypes. The Przybrodzka variety was donated by the Institute of Soil Science and Plant Cultivation (Poznań, Poland) to the US National Plant Germplasm System (NPGS) in 1966.

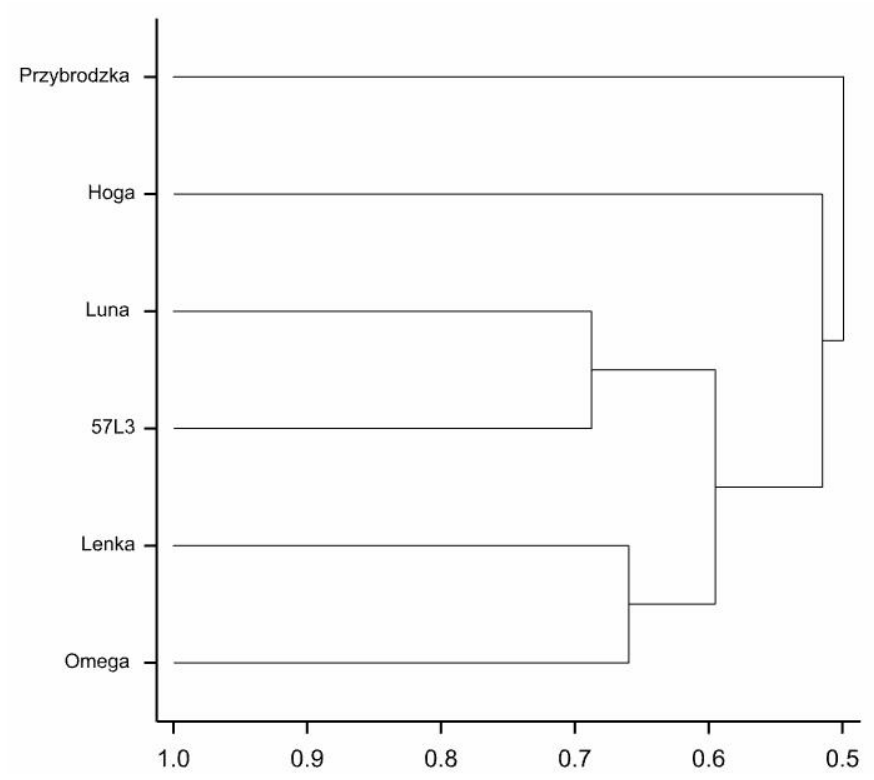

Figure 1. A dendrogram of Camelina sativa genotypes. The cultivars were grouped hierarchically using the unweighted pair group method of arithmetic means (UPGMA).

\subsection{Greenhouse Experiment}

Quizalofop-p-ethyl and propaquizafop caused the smallest damage to all camelina varieties and genotypes. At 21 days after the use of propaquizafop, the largest damage (15\%) was observed on the Omega variety (Table 1). In the assessment at 42 DAT (Table 2), no statistically significant camelina damage was found after the use of these herbicides. The greatest damage occurred after using herbicides from the group of synthetic auxin herbicides (clopyralid, picloram). Picloram caused the most damage to camelina and Luna at 21 DAT. Unlike graminicides, damage after clopyralid and picloram was not completely transient, and their levels were still high. In the assessment carried out 42 DAT, the largest damages $(30 \%, 30 \%, 25 \%$, respectively) were observed on the Hoga genotype and on the Omega and Luna varieties. The smallest damage after using picloram was found on the variety Przybrodzka and genotype Lenka and after the application of clopyralid on the Przybrodzka variety and genotypes Lenka and 57 L3. In the experiment, the mass of plants was analyzed. However, the results were not presented in the results and discussions. The reason is a problem with drawing reliable conclusions for this parameter. 
Table 1. Visual assessment of phytotoxicity (\%) 21 days after treatment (21 DAT).

\begin{tabular}{cccccccc}
\hline \multirow{2}{*}{ Treatment } & \multicolumn{7}{c}{ Varieties/Genotypes } \\
\cline { 2 - 8 } & Przybrodzka & Lenka & Luna & Omega & Hoga & 57 L3 & LSD (0.05) \\
\hline Untreated & 0 & 0 & 0 & 0 & 0 & 0 & - \\
Propaquizafop & $\mathrm{C}$ & $\mathrm{D}$ & $\mathrm{E}$ & $\mathrm{E}$ & $\mathrm{C}$ & $\mathrm{C}$ & \\
70 g a.i. ha $^{-1}$ & $10 \mathrm{~b}$ & $0 \mathrm{c}$ & $10 \mathrm{~b}$ & $15 \mathrm{a}$ & $10 \mathrm{~b}$ & $7.5 \mathrm{~b}$ & 2.9 \\
Quizalofop-p-ethyl & $\mathrm{B}$ & $\mathrm{D}$ & $\mathrm{C}$ & $\mathrm{C}$ & $\mathrm{B}$ & $\mathrm{B}$ & \\
50 g a.i. ha $^{-1}$ & $\mathrm{cc}$ & $7.5 \mathrm{ab}$ & $5 \mathrm{~b}$ & $10 \mathrm{a}$ & $0 \mathrm{c}$ & $0 \mathrm{c}$ & 3.1 \\
Clopyralid & $\mathrm{C}$ & $\mathrm{C}$ & $\mathrm{D}$ & $\mathrm{D}$ & $\mathrm{C}$ & $\mathrm{C}$ & \\
90 g a.i.* ha ${ }^{-1}$ & $10 \mathrm{~d}$ & $22.5 \mathrm{c}$ & $20 \mathrm{c}$ & $35 \mathrm{ab}$ & $40 \mathrm{a}$ & $32.5 \mathrm{~b}$ & 5.7 \\
Picloram & $\mathrm{B}$ & $\mathrm{A}$ & $\mathrm{B}$ & $\mathrm{B}$ & $\mathrm{A}$ & $\mathrm{A}$ & \\
24 g a.i. ha $^{-1}$ & $20 \mathrm{~d}$ & $20 \mathrm{~d}$ & $55 \mathrm{a}$ & $45 \mathrm{~b}$ & $40 \mathrm{bc}$ & $35 \mathrm{c}$ & 7.2 \\
LSD $(0.05)$ & $\mathrm{A}$ & $\mathrm{B}$ & $\mathrm{A}$ & $\mathrm{A}$ & $\mathrm{A}$ & $\mathrm{A}$ & \\
\hline
\end{tabular}

$0 \%$ (untreated) to $100 \%$ (completely destroyed plant); a-e and A-E different letters indicate statistically different mean LSD $(p<0.05)$; capital letters-vertical, e.g. A; lower-case letters-horizontal, e.g., a.

Table 2. Visual assessment of phytotoxicity (\%) 42 days after treatment (42 DAT).

\begin{tabular}{|c|c|c|c|c|c|c|c|}
\hline \multirow{2}{*}{ Treatment } & \multicolumn{7}{|c|}{ Varieties/Genotypes } \\
\hline & Przybrodzka & Lenka & Luna & Omega & Hoga & $57 \mathrm{L3}$ & LSD (0.05) \\
\hline \multirow{2}{*}{ Untreated } & 0 & 0 & 0 & 0 & 0 & 0 & \multirow{2}{*}{-} \\
\hline & $\mathrm{C}$ & $\mathrm{C}$ & $\mathrm{C}$ & $\mathrm{D}$ & $\mathrm{D}$ & $\mathrm{D}$ & \\
\hline Propaquizafop & $0 \mathrm{a}$ & $0 \mathrm{a}$ & $0 \mathrm{a}$ & $10 \mathrm{a}$ & $10 \mathrm{a}$ & $5 a$ & \multirow{2}{*}{ n.s. } \\
\hline $70 \mathrm{~g} \mathrm{a.i.}^{*} \mathrm{ha}^{-1}$ & $\mathrm{C}$ & $\mathrm{C}$ & $\mathrm{C}$ & $\mathrm{C}$ & $\mathrm{C}$ & $\mathrm{C}$ & \\
\hline Quizalofop-p-ethyl & $0 \mathrm{a}$ & $0 \mathrm{a}$ & $0 \mathrm{a}$ & $10 \mathrm{a}$ & $10 \mathrm{a}$ & $0 \mathrm{a}$ & \multirow[b]{2}{*}{ n.s. } \\
\hline $50 \mathrm{~g}_{\text {a.i. }}{ }^{*} \mathrm{ha}^{-1}$ & $\mathrm{C}$ & $\mathrm{C}$ & $\mathrm{C}$ & $\mathrm{C}$ & $\mathrm{C}$ & $\mathrm{D}$ & \\
\hline Clopyralid & $7.5 \mathrm{c}$ & $7.5 \mathrm{c}$ & $15 b$ & $20 \mathrm{a}$ & $20 \mathrm{a}$ & $10 \mathrm{c}$ & \multirow{2}{*}{3.2} \\
\hline 90 g a.i. ${ }^{*} \mathrm{ha}^{-1}$ & B & B & B & B & B & B & \\
\hline Picloram & $15 \mathrm{~cd}$ & $10 \mathrm{~d}$ & $25 \mathrm{ab}$ & $30 a$ & $30 a$ & $20 b c$ & \multirow[b]{2}{*}{5.3} \\
\hline 24 g a.i. ${ }^{*} \mathrm{ha}^{-1}$ & A & A & A & A & A & A & \\
\hline $\operatorname{LSD}(0.05)$ & 1.9 & 1.9 & 3.9 & 1.4 & 2.6 & 3.2 & - \\
\hline
\end{tabular}

n. s.- - no significant differences; $0 \%$ (untreated) to $100 \%$ (completely destroyed plant); a-e and A-E different letters indicate statistically different mean LSD $(p<0.05)$; capital letters-vertical, e.g., A; lower-case letters-horizontal, e.g., a.

\subsection{Plant Chlorophyll Fluorescence}

Chlorophyll fluorescence was measured 14 and 21 days after herbicide application. Averages of results of herbicide effects on plant chlorophyll fluorescence for all genotypes are shown. The measurement at the first date showed no significant differences in the parameters: Fv (Figure 2) and Fm (Figure 3). However, significant differences were noted in the $\mathrm{Fv} / \mathrm{Fm}$ parameter (Figure 4). They were observed in all combinations where herbicides were used, relative to the values obtained for the unsprayed control. The highest decrease in Maximum Photochemical Efficiency of Photosystem II was found in plants sprayed with picloram. During the second, subsequent measurement, significant differences were found between the preparations used in all three parameters of chlorophyll fluorescence measurement: Fm, Fv, and Fv/Fm. Similar to the case of changes in the Fv/Fm parameter value, a significant decrease in Fm and Fv parameters was observed in all sprayed objects relative to the control, to the greatest extent in plants treated with picloram and to the smallest those treated with quizalofop-p-ethyl and propaquizafop. The highest decrease in Fm and Fv parameters in relation to the unsprayed control was recorded for objects treated with picloram. The measurements showed no significant differences in the parameter F0 (data not shown). 


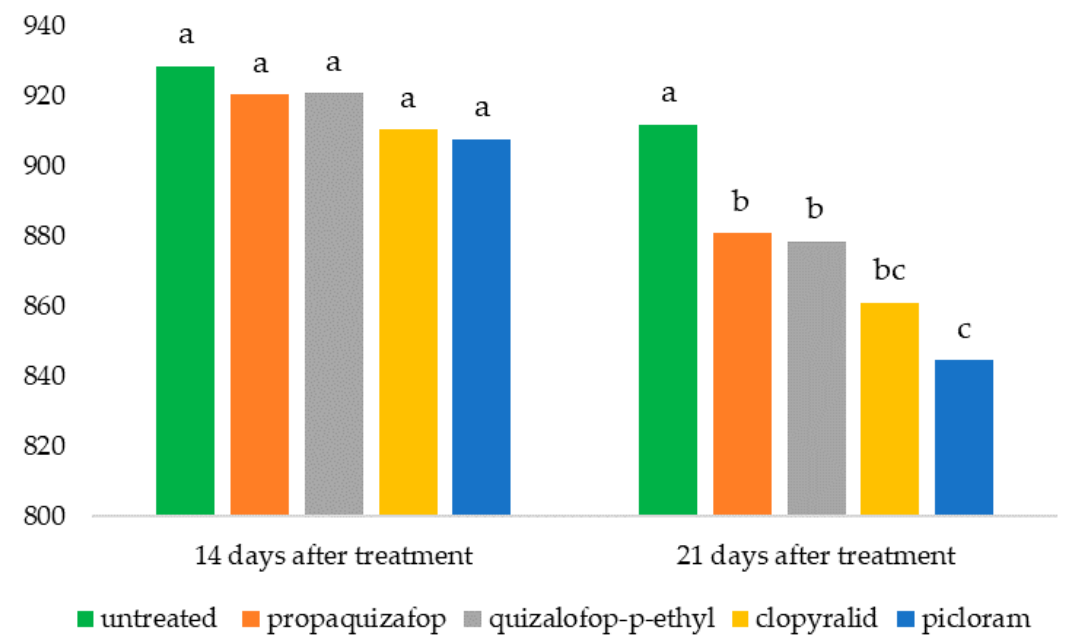

Figure 2. The effect of herbicides on $\mathrm{Fv}$-variable fluorescence (non-nominated units). Different letters $\left({ }^{\mathrm{a}-\mathrm{c}}\right)$ indicate statistically different mean LSD $(p<0.05) 14$ DAA $=19.52 ; \mathrm{LSD}(p<0.05) 21 \mathrm{DAA}=25.91$; DAA—days after herbicides application.

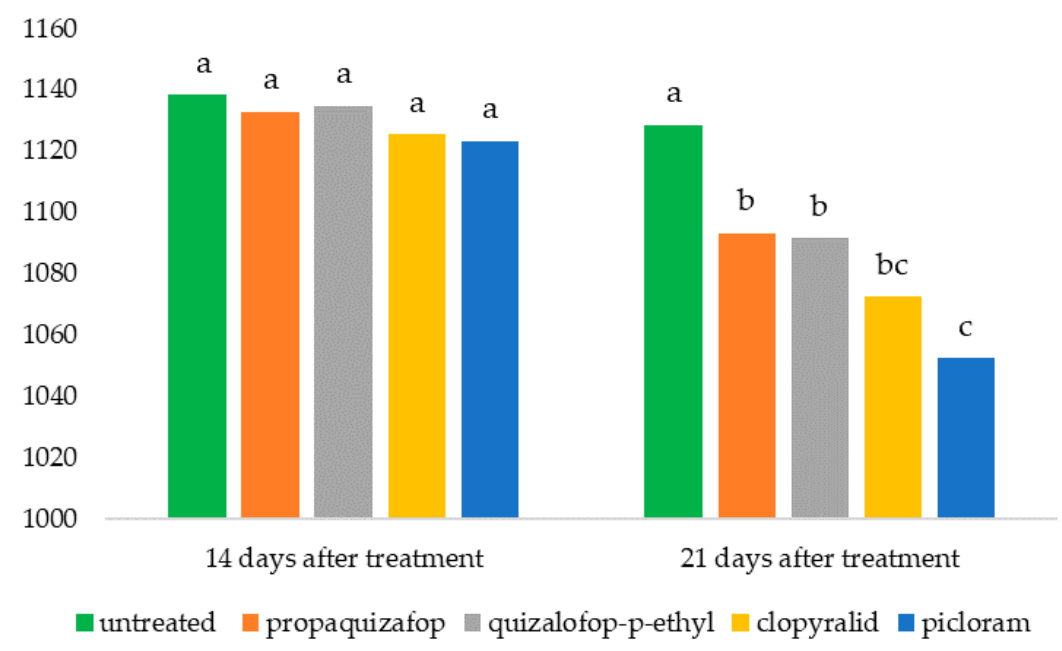

Figure 3. The effect of herbicides on Fm-maximum fluorescence (non-nominated units). Different letters $\left({ }^{\mathrm{a}-\mathrm{c}}\right)$ indicate statistically different mean LSD $(p<0.05) 14$ DAA $=23.80$; LSD $(p<0.05) 21$ DAA $=32.17$; DAA—days after herbicides aplication. 


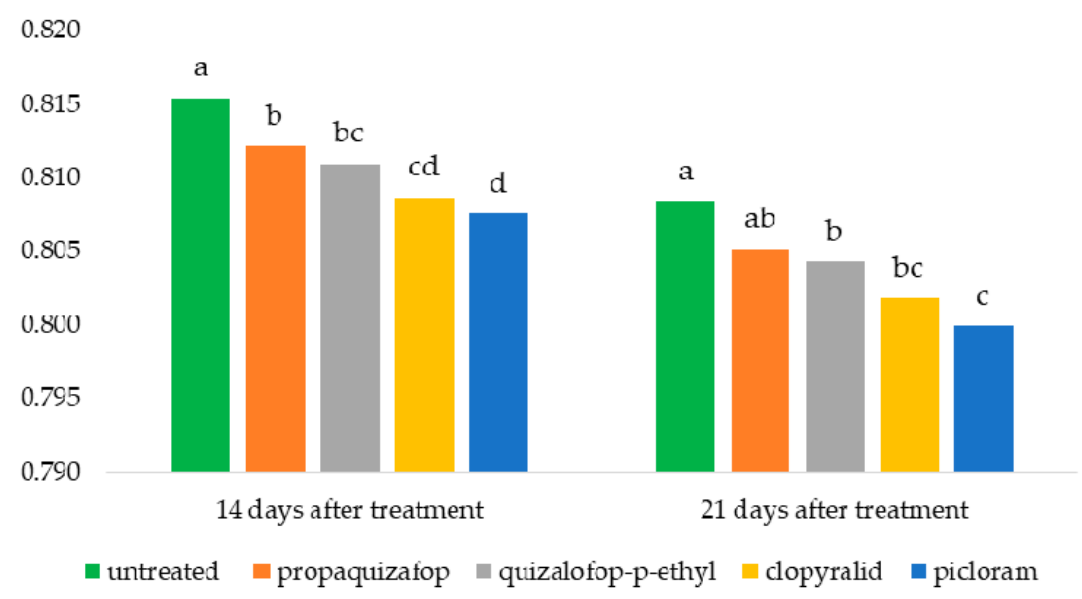

Figure 4. The effect of herbicides on Fv/Fm-maximum Photochemical Efficiency of Photosystem II (non-nominated units). Different letters $\left({ }^{\mathrm{a}-\mathrm{c}}\right)$ indicate statistically different mean LSD $(p<0.05) 14$ $\mathrm{DAA}=0.029 ; \mathrm{LSD}(p<0.05) 21 \mathrm{DAA}=0.0036$; DAA—days after herbicides aplication .

\section{Discussion}

The phytotoxicity of herbicides towards a crop means exceeding the maximum protective capacity of this plant related to the mechanisms of selectivity or the possibility of detoxification of these substances [48]. Selective herbicides can therefore cause transient stress in crop plants [49]. In some cases, they can damage plants and reduce yields [50].

In the conducted experiment, propaquizafop and quizalofop-P-ethyl contributed to the inhibition of plant growth. For most varieties and genotypes, however, these were transient symptoms. Quizalofop-P-ethyl is a registered substance for use on camelina plantations in different parts of the world $[13,22]$. This substance is therefore widely used in practice to control monocotyledonous weeds in this crop. According to data available in the literature, propaquizafop contributed little to the phytotoxicity effect on Indian mustard [51]. Damage was also observed in the case of the application of other substances classified as acetyl coenzyme A carboxylase inhibitors in canola cultivation [52]. These plants, like camelina, belong to the Brassicaceae family. The results of the conducted research indicate that substances belonging to synthetic auxin herbicides have contributed to greater damage to plants than graminicides. The application of these preparations resulted in twisting of camelina leaves. Picloram has the highest degree of phytotoxicity. Slight damage caused by picloram and aminopyralid (also included in synthetic auxin herbicides) in relation to some species of plants belonging to Brassicaceae were also noted in other papers [53]. The Przybrodzka variety was characterized by the smallest genetic similarity in relation to all tested varieties and genotypes. At the same time, it was characterized by the greatest tolerance to the effects of applied substances. In the case of other varieties and genotypes, no relationship between genetic similarity and sensitivity to the herbicides used was observed.

The herbicides used in the study included synthetic auxins. Substances belonging to this group may cause calluses of plants, which affect their mass [54]. It is estimated that for studies using synthetic auxins, visual assessment of phytotoxicity is more desirable than testing the weight of plants [55].

One of the biggest problems associated with camelina breeding is the low diversity within this species. In addition, only spring camelina genotypes were collected in gene banks. Due to the low intraspecific variability, breeders look for variability of related species and genera, or induce variation through mutagenesis or due to genetic engineering [56]. Analysis of the genetic similarity of spring genotypes (currently grown in Poland and Ukraine) and winter varieties of Camelina sativa (which are traditionally grown only in Western Europe) was performed by Kurasiak-Popowska et al. (2018) [56]. Apart from the 'Przybrodzka' cultivar, the Polish cultivars of spring and winter camelina were included in one similarity group. The plant material for this publication was selected based on the results of 
molecular analyses, yielding, and the content of chemical compounds in camelina genotypes collected at the University of Life Sciences in Poznan [56,57].

An important factor influencing the herbicidal effectiveness of herbicides is the formulation of the preparations [58]. The type of formulation also plays an important role in relation to herbicide phytotoxicity to the crop [59]. In the experiment, quizalofop-p-ethyl and propaquizafop were used in the EC (emulisfiable concentrate) formulation. This formulation is a mixture of pesticides, adjuvants, and emulsifiers that are dissolved in oil. Together with the water in the sprayer tank, they form a diluted, stable emulsion. One of the disadvantages of this formulation, however, is the possibility of damage to the leaves of crop plants [60]. The oil-based adjuvants contained in the herbicide formulation may contribute to the dissolution of the wax layer covering the surface of the crop [61]. Oil adjuvants work in a similar way and are included in the composition of the spray liquid. In some cases, they increase the risk of phytotoxicity but at the same time contribute to improving the herbicidal herbicide effectiveness [62]. Most of the graminicides available on the market occur in the EC formulation, which due to the oil content can cause damage to some plants. In our research, herbicides from the aryloxyphenoxypropionates group that control monocotyledonous weeds were phytotoxic for some genotypes of camelina because they were in EC formulation, injurious for cuticular wax.

The Fv/Fm parameter is considered to be a reliable indicator of the photochemical activity of the photosynthetic apparatus, and its reduction indicates the occurrence of stress in plants, the consequence of which is damage to the PSII function [63]. During both the first and second measurements, a significant decrease in the $\mathrm{Fv} / \mathrm{Fm}$ parameter (maximum photochemical efficiency of PSII) was observed. However, according to studies of other authors $[63,64]$, the obtained values do not indicate strong damage, and it can be concluded that they did not affect the health of plants. The Fv/Fm value for unstressed control of most plant species is close to $0.83[65,66]$. The decrease in the Fm parameter-maximum fluorescence-indicates the occurrence of stress in plants, the effect of which means that not all electron acceptors in PSII can be completely reduced [67]. In turn, a decrease in the Fv parameter-variable fluorescence-may indicate a decrease in PSII activity and scattering of excitation energy in the form of heat [63]. However, the level of the obtained parameters indicates slight damage to the PSII. The measurements were to show the trend of plant stress caused by individual herbicides, but the level of this reaction, due to the selected mechanisms of herbicide action, did not indicate high stress of the plants; hence, the average results for genotypes were shown. Larger differences in the response of individual genotypes were found in the visual assessment; therefore, the results of visual observation are presented separately for individual genotypes. However, the trend in plant reactions was the same for both parameters-for plant chlorophyll fluorescence and visual assessment: the highest plant damage was observed for picloram and the lowest for ACCase inhibitors. Dayan et al. (2012) [40], studying the mechanisms of herbicide action using chlorophyll fluorescence, showed that the effect on photosynthesis caused by herbicides from the group of aryloxyphenoxypropionate inhibitors of ACCase was very modest on cucumber cotyledons, which may be due to the grass selectivity of this herbicide. In the same research, some herbicides acting as superauxins did not affect photosynthesis in the cucumber cotyledon assay. It can therefore be concluded that the decrease in fluorescence parameters as a consequence of spraying is secondary and results from leaf damage caused by herbicide injury, and the photosynthetic activity carried out is proportional to the surface of the undamaged leaf.

\section{Conclusions}

The small number of herbicides registered for use on camelina plantations makes weeds a difficult problem. The conducted research determined the genetic distance between different varieties and genotypes of camelina (spring and winter forms). The effect of individual herbicides on chlorophyll fluorescence was tested. The Przybrodzka variety was characterized by the greatest genetic distance in relation to other varieties and genotypes. At the same time, it was highly resistant to phytotoxic effects of herbicides. For the other varieties and genotypes, no similar relationship was observed. Damage 
to camelina after herbicide application was largely transient. Among the substances used, picloram contributed most to the occurrence of phytotoxicity. Plant fluorescence measurements indicate that PSII damage was not large and plants have a chance of regeneration. Further research is needed on the possibility of using various herbicides in camelina and other minor crops. It should be carried out taking into account the effect of the substance on individual plant varieties.

Supplementary Materials: The following are available online at http://www.mdpi.com/2077-0472/10/5/185/s1, Table S1. Nucleic sequences of random amplified polymorphic DNA (RAPD-PCR) primers.

Author Contributions: Conceptualization, Ł.S.; methodology, Ł.S. and D.K.-P.; data curation, Ł.S., M.G., D.K.-P.; writing - original draft preparation, Ł.S., M.G., D.K.-P. and D.R.; writing—review and editing, Ł.S., M.G., D.K.-P. and D.R.; visualization, Ł.S. and D.K.-P.; supervision, Ł.S. All authors have read and agreed to the published version of the manuscript.

Funding: The publication was co-financed within the framework of Ministry of Science and Higher Education programme as "Regional Initiative Excellence" in years 2019-2022, Project No. 005/RID/2018/19.

Conflicts of Interest: The authors declare no conflict of interest.

\section{References}

1. Barbieri, P.; Pellerin, S.; Nesme, T. Comparing crop rotations between organic and conventional farming. Sci. Rep. 2017, 7, 1-10. [CrossRef] [PubMed]

2. Kremen, C.; Iles, A.; Bacon, C. Diversified Farming Systems: An Agroecological, Systems-based Alternative to Modern Industrial Agriculture. Ecol. Soc. 2012, 17, 44. [CrossRef]

3. Sawinska, Z.; Świtek, S.; Głowicka-Wołoszyn, R.; Kowalczewski, P.Ł. Agricultural Practice in Poland Before and after Mandatory IPM Implementation by the European Union. Sustainability 2020, 12, 1107. [CrossRef]

4. Kurasiak-Popowska, D. Lnianka siewna-Roślina historyczna czy perspektywiczna? Fragm. Agron. 2019, 36, $42-54$.

5. Bandurska, H.; Niedziela, J.; Pietrowska-Borek, M.; Nuc, K.; Chadzinikolau, T.; Radzikowska, D. Regulation of proline biosynthesis and resistance to drought stress in two barley (Hordeum vulgare L.) genotypes of different origin. Plant Physiol. Biochem. 2017, 118, 427-437. [CrossRef]

6. Vogel, E.; Donat, M.G.; Alexander, L.V.; Meinshausen, M.; Ray, D.K.; Karoly, D.; Meinshausen, N.; Frieler, K. The effects of climate extremes on global agricultural yields. Environ. Res. Lett. 2019, 14, 1-12. [CrossRef]

7. Iskandarov, U.; Kim, H.J.; Cahoon, E.B. Camelina: An Emerging Oilseed Platform for Advanced Biofuels and Bio-Based Materials. In Plants and bioenergy; Carpita, N., McCann, M., Buckeridge, M.S., Eds.; Springer Science \& Business Media: New York, NY, USA, 2014; pp. 131-140.

8. Vollmann, J.; Steinkellner, S.; Glauninger, J. Variation in resistance of camelina (Camelina sativa (L.) Crtz.) to downy mildew (Peronospora camelinae Gäum.). J. Phytopathol. 2001, 149, 129-133. [CrossRef]

9. Lenssen, A.W.; Iversen, W.M.; Sainju, U.M.; Caesar-TonThat, T.C.; Blodgett, S.L.; Allen, B.L.; Evans, R.G. Yield, Pests, and Water Use of Durum and Selected Crucifer Oilseeds in Two-Year Rotations. Agron. J. 2012, 104, 1295-1304. [CrossRef]

10. Román-Figueroa, C.; Padilla, R.; Uribe, J.M.; Paneque, M. Land Suitability Assessment for Camelina (Camelina sativa L.) Development in Chile. Sustainability 2017, 9, 154. [CrossRef]

11. Nguyen, H.T.; Silva, J.E.; Podicheti, R.; Macrander, J.; Yang, W.; Nazarenus, T.J.; Nam, J.-W.; Jaworski, J.G.; Lu, C.; Scheffler, B.E.; et al. Camelina seed transcriptome: A tool for meal and oil improvement and translational research. Plant Biotechnol. J. 2013, 11, 759-769. [CrossRef]

12. Lu, C.; Napier, J.A.; Clemente, T.E.; Cahoon, E.B. New frontiers in oilseed biotechnology: Meeting the global demand for vegetable oils for food, feed, biofuel, and industrial applications. Curr. Opin. Biotechnol. 2011, 22, 252-259. [CrossRef] [PubMed]

13. Berti, M.; Gesch, R.; Eynck, C.; Anderson, J.; Cermak, S. Camelina uses, genetics, genomics, production, and management. Ind. Crops Prod. 2016, 94, 690-710. [CrossRef]

14. Goímez-Monedero, B.; Bimbela, F.; Arauzo, J.S.; Faria, J.; Ruiz, M.P. Pyrolysisof red eucalyptus, camelina straw, and wheat straw in an ablative reactor. Energy Fuels 2015, 29, 1766-1775. [CrossRef]

15. Eynck, C.; Falk, K.C. Camelina (Camelina sativa). In CAB International 2013. Biofuel Crops: Production, Physiology and Genetics; Singh, B.P., Ed.; Fort Valley State University: Fort Valley, GA, USA, 2013; pp. 369-391. 
16. Kurasiak-Popowska, D.; Stuper-Szablewska, K.; Nawracała, J. Olej rydzowy jako naturalne źródło karotenoidów dla przemysłu kosmetycznego. Przem. Chem. 2017, 96, 2077-2080. [CrossRef]

17. Kim, N.; Li, Y.; Sun, X.S. Epoxidation of Camelina sativa oil and peel adhesion properties. Ind. Crops. Prod. 2015, 64, 1-8. [CrossRef]

18. Hixson, S.M.; Parrish, C.C.; Anderson, D.M. Full substitution of fish oil with camelina (Camelina sativa) oil, with partial substitution of fish meal with camelina meal, in diets for farmed Atlantic salmon (Salmo salar) and its effecton tissue lipids and sensory quality. Food Chem. 2014, 157, 51-61. [CrossRef]

19. Woyengo, T.A.; Patterson, R.; Slominski, B.A.; Beltranena, E.; Zijlstra, R.T. Nutritive value of cold-pressed camelina cake with or without supplementation of multi-enzyme in broiler chicken. Poultry Sci. 2016, 95, 2314-2321. [CrossRef]

20. Moser, B.R. Camelina (Camelina sativa L.) oils as a biofuels feedstock: Golden opportunity or false hope? Lipid Technol. 2010, 22, 270-273. [CrossRef]

21. Chu, P.L.; Vanderghem, C.; MacLean, H.L.; Saville, B.A. Financial analysis and risk assessment of hydroprocessed renewable jet fuel production from camelina, carinata and used cooking oil. Appl. Energy 2017, 198, 401-409. [CrossRef]

22. Matyjaszczyk, E. Protection possibilities of agricultural minor crops in the European Union: A case study of soybean, lupin and camelina. J. Plant. Dis. Prot. 2020, 127, 55-61. [CrossRef]

23. Pullens, J.W.M.; Sharif, B.; Trnka, M.; Balek, J.; Semenov, M.A.; Olesen, J.E. Risk factors for European winter oilseed rape production under climate change. Agric. For. Meteorol. 2019, 272, 30-39. [CrossRef]

24. Available online: www.gov.pl/web/rolnictwo/wyszukiwarka-srodkow-ochrony-roslin (accessed on 14 April 2020).

25. Bountin, C.; Aya, K.L.; Carpenter, D.; Thomas, P.J.; Rowland, O. Phytotoxicity testing for herbicide regulation: Shortcomings in relation to biodiversity and ecosystem services in agrarian systems. Sci. Total Environ. 2012, 415, 79-92. [CrossRef] [PubMed]

26. Singh, S.P.; Rawal, S.; Dua, V.K.; Roy, S.; Sadaworti, M.J.; Sharma, S.K. Evaluation of propaquizafop: A new molecule as post emergence herbicide in potato. Int. J. Chem. Stud. 2017, 5, 1216-1220.

27. Bradley, K.W.; Wu, J.; Hatzios, K.K.; Hagood, E.S. The mechanism of resistance to aryloxyphenoxypropionate and cyclohexanedione herbicides in a johnsongrass biotype. Weed Sci. 2001, 49, 477-484. [CrossRef]

28. Délye, C.; Calmès, É.; Matéjicek, A. SNP markers for black-grass (Alopecurus myosuroides Huds.) genotypes resistant to acetyl CoA-carboxylase inhibiting herbicides. Theor. Appl. Genet. 2002, 104, 1114-1120. [CrossRef] [PubMed]

29. Ohlrogge, J.; Browse, J. Lipid Biosynthesis. Plant Cell 1995, 7, 957-970.

30. Ali, K.; Tyagi, A. Recent advances in acetyl CoA carboxylase: A key enzyme of fatty acidbiosynthesis in plants. Int. J. Appl. Biol. Pharm. 2016, 7, 264-277.

31. Konishi, T.; Shinohara, K.; Yamada, K.; Sasaki, Y. Acetyl-CoA Carboxylase in Higher Plants: Most Plants Other Than Gramineae Have Both the Prokaryotic and the Eukaryotic Forms of This Enzyme. Plant Cell Physiol. 1996, 37, 117-122. [CrossRef]

32. Konishi, T.; Sasaki, Y. Compartmentalization of two forms of acetyl-CoA carboxylase in plants and the origin of their tolerance toward herbicides. Proc. Natl. Acad. Sci. USA 1994, 91, 3598-3601. [CrossRef]

33. Busi, R.; Goggin, D.E.; Heap, I.M.; Horak, M.J.; Jugulam, M.; Masters, R.A.; Napier, R.M.; Riar, D.S.; Satchivi, N.M.; Torra, J.; et al. Weed resistance to synthetic auxin herbicides. Pest Manag. Sci. 2018, 74, 2265-2276. [CrossRef]

34. Grossmann, K. Mediation of Herbicide Effects by Hormone Interactions. J. Plant Growth Regul. 2003, 22, 109-122. [CrossRef]

35. McSteen, P. Auxin and Monocot Development. Cold Spring Harb. Perspect. Biol. 2010, 2, a001479. [CrossRef] [PubMed]

36. Gottardini, E.; Cristofori, A.; Cristofolini, F.; Nali, C.; Pellegrini, E.; Bussotti, F.; Ferretti, M. Chlorophyll-related indicators are linked to visible ozone symptoms: Evidence from a field study on native Viburnum lantana $\mathrm{L}$. plants in northern Italy. Ecol. Ind. 2014, 39, 65-74. [CrossRef]

37. Juneau, P.; Qiu, B.; Deblois, C. Use of chlorophyll fluorescence as a tool for determination of herbicide toxic effect: Review. Toxicol. Environ. Chem. 2007, 89, 609-625. [CrossRef] 
38. Kalaji, H.M.; Schansker, G.; Brestic, M.; Bussotti, F.; Calatayud, A.; Ferroni, L.; Goltsev, V.; Guidi, L.; Jajoo, A.; Li, P.; et al. Frequently asked questions about chlorophyll fluorescence, the sequel. Photosyn. Res. 2017, 132, 13-66. [CrossRef]

39. Kaiser, Y.I.; Menegat, A.; Gerhards, R. Chlorophyll fluorescence imaging: A new method for rapid detection of herbicide resistance in Alopecurus myosuroides. Weed Res. 2013, 53, 399-406. [CrossRef]

40. Dayan, F.E.; de Zaccaro, M.L. Chlorophyll fluorescence as a marker for herbicide mechanisms of action. Pestic. Biochem. Phys. 2012, 102, 189-197. [CrossRef]

41. Kalaji, H.M.; Jajoo, A.; Oukarroum, A.; Brestic, M.; Zivcak, M.; Samborska, I.A.; Cetner, M.D.; Łukasik, I.; Goltsev, V.; Ladle, R.J. Chlorophyll a fluorescence as a tool to monitor physiological status of plants under abiotic stress conditions. Acta Physiol. Plant. 2016, 38, 102. [CrossRef]

42. Kurasiak-Popowska, D.; Ryńska, B.; Stuper-Szablewska, K. Analysis of distribution of selected bioactive compounds in Camelina sativa from seeds to pomace and oil. Agronomy 2019, 9, 168. [CrossRef]

43. Manca, A.; Pecchia, P.; Mapelli, S.; Masella, P.; Galasso, I. Evaluation of genetic diversity in a Camelina sativa (L.) Crantz collection using microsatellite markers and biochemical traits. Genet. Resour. Crop Evol. 2013, 60, 1223-1236. [CrossRef]

44. Nei, M.; Li, W.H. Mathematical model for studying genetic variation in terms of restriction endonucleases. Proc. Natl. Acad. Sci. USA 1979, 76, 5269-5273. [CrossRef] [PubMed]

45. Smith, J.; Wherley, B.; Reynolds, C.; White, R.; Senseman, S.; Falk, S. Weed control spectrum and turfgrass tolerance to bioherbicide Phoma macrostoma. Int. J. Pest. Manag. 2015, 61, 91-98. [CrossRef]

46. Available online: https://www.eppo.int/RESOURCES/eppo_standards/pp1_list (accessed on 2 May 2020).

47. Kowalczewski, P.Ł.; Radzikowska, D.; Ivanišová, E.; Szwengiel, A.; Kačániová, M.; Sawinska, Z. Influence of Abiotic Stress Factors on the Antioxidant Properties and Polyphenols Profile Composition of Green Barley (Hordeum vulgare L.). Int. J. Mol. Sci. 2020, 21, 397. [CrossRef] [PubMed]

48. de Carvalho, S.J.P.; Nicolai, M.; Ferreira, R.R.; de Oliveira Figueira, A.V.; Christoffoleti, P.J. Herbicide selectivity by differential metabolism: Considerations for reducing crop damages. Sci. Agric. 2009, 66, 136-142. [CrossRef]

49. Dyer, W.E.; Weller, S.C. Plant response to herbicides. In Plant Abiotic Stress; Jenks, M., Hasegawa, P.M., Eds.; Blackwell Publishing Ltd.: Oxford, UK; Ames, IA, USA, 2005; pp. 171-214.

50. Young, B.G.; Young, J.M.; Matthews, J.L.; Owen, M.D.K.; Zelaya, I.A.; Hartzler, R.G.; Wax, L.M.; Rorem, K.W.; Bollero, G.A. Soybean Development and Yield as Affected by Three Postemergence Herbicides. Agron. J. 2003, 95, 1152-1156. [CrossRef]

51. Gupta, S.; Sharma, P.K.; Kumar, S.; Singh, S.; Singh, S.; Yadav, H.L. Effect of herbicides and fertilizers on the phytotoxicity, growth and yield of Indian mustard [Brassica juncea (L.) Czern and Coss.]. J. Pharmacogn. Phytochem. 2019, 8, 2451-2454.

52. Mohamed, I.A. Efficiency of Some Post Emergence Acetyl Coenzyme a Carboxylase-Inhibitor Herbicides Against Certain Grassy Weeds in Canola Fields. Egypt. Acad. J. Biolog. Sci. 2017, 8, 49-58. [CrossRef]

53. Harris, B.M.; Bath, S.; Degenhardt, R. Safening Aminopyralid Compositions in Brassica Species with Clopyralid and Methods of Use Thereof. U.S. Patent Application No 15/611,956, 14 December 2017.

54. Roskamp, J.M.; Chahal, G.S.; Johnson, W.G. The Effect of Cations and Ammonium Sulfate on the Efficacy of Dicamba and 2,4-D. Weed Technol. 2013, 27, 72-77. [CrossRef]

55. Dowler, C.C. A cucumber bioassay test for the soil residues of certain herbicides. Weed Sci. 1969, 17, 309-310. [CrossRef]

56. Kurasiak-Popowska, D.; Tomkowiak, A.; Czołpińska, M.; Bocianowski, J.; Weigt, D.; Nawracała, J. Analysis of yield and genetic similarity of Polish and Ukrainian Camelina sativa genotypes. Ind. Crop. Prod. 2018, 123, 667-675. [CrossRef]

57. Kurasiak-Popowska, D.; Stuper-Szablewska, K. The phytochemical quality of Camelina sativa seed and oil. Acta Agric. Scand. Sect. B-Soil Plant Sci. 2020, 70, 39-47. [CrossRef]

58. Kudsk, P. Optimising herbicide dose: A straightforward approach to reduce the risk of side effects of herbicides. Environmentalist 2008, 28, 49-55. [CrossRef]

59. Mashayamombe, B.K.; Mazarura, U.; Chiteka, A. The Effect of Two Formulations of Sulfentrazone on Soil and Leaf Residues and Phytotoxicity in Tobacco (Nicotiana Tabacum L.). Asian J. Agric. Dev. 2013, 3, 135-140.

60. Hazra, D.K.; Purkait, A. Role of pesticide formulations for sustainable crop protection and environment management: A review. J. Pharmacogn. Phytochem. 2019, 8, 686-693. 
61. Hazen, J.L. Adjuvants-Terminology, Classification, and Chemistry. Weed Technol. 2000, 14, 773-784. [CrossRef]

62. Zhang, J.; Jaeck, O.; Menegat, A.; Zhang, Z.; Gerhards, R.; Ni, H. The Mechanism of Methylated Seed Oil on Enhancing Biological Efficacy of Topramezone on Weeds. PLoS ONE 2013, 8, e74280. [CrossRef]

63. Kalaji, M.H.; Łoboda, T. Fluorescencja Chlorofilu w Badanach Stanu Fizjologicznego Roślin; SGGW Publisher: Warsaw, Poland, 2010; p. 116.

64. Cetner, M.D.; Dabrowski, P.; Samborska, I.A.; Łukasik, I.; Swoczyna, T.; Pietkiewicz, S.; Bąba, W.; Kalaji, H.M. Zastosowanie pomiarów fluorescencji chlorofilu w badaniach środowiskowych. Kosmos 2016, 65, 197-205.

65. Björkman, O.; Demmig, B. Photon yield of $\mathrm{O}_{2}$ evolution and chlorophyll fuorescence characteristics at $77 \mathrm{k}$ among vascular plants of diverse origins. Planta 1987, 170, 489-504. [CrossRef]

66. Radzikowska, D.; Grzanka, M.; Kowalczewski, P.-Ł.; Głowicka-Wołoszyn, R.; Blecharczyk, A.; Nowicki, M.; Sawinska, Z. Influence of SDHI Seed Treatment on the Physiological Conditions of Spring Barley Seedlings under Drought Stress. Agronomy 2020, 10, 731. [CrossRef]

67. Sayed, O.H. Chlorophyll Fluorescence as a Tool in Cereal Crop Research. Photosynthetica 2003, 41, 321-330. [CrossRef]

(C) 2020 by the authors. Licensee MDPI, Basel, Switzerland. This article is an open access article distributed under the terms and conditions of the Creative Commons Attribution (CC BY) license (http://creativecommons.org/licenses/by/4.0/). 